ISSN = 1980-993X - doi:10.4136/1980-993X
www.agro.unitau.br/ambi-agua
E-mail: ambi-agua@agro.unitau.br
Tel.: (12) 3625-4116

\title{
Mercury Bioaccumulation in the Brazilian Amazonian Tucunares (Cichla sp., Cichlidae, Perciformes)
} (doi:10.4136/ambi-agua.49)

\author{
Ysrael Marrero Vera ${ }^{1}$; Roberto José de Carvalho ${ }^{2}$; \\ Zuleica Carmen Castilhos ${ }^{3}$; Maria Josefina Reyna Kurtz ${ }^{4}$ \\ ${ }^{1}$ Departamento de Ciência dos Materiais e Metalurgia - PUC-Rio \\ E-mail: ysrael@gmail.com \\ ${ }^{2}$ Departamento de Ciência dos Materiais e Metalurgia - PUC-Rio \\ E-mail: rjcar@dcmm.puc-rio.br \\ ${ }^{3}$ Centro de Tecnologia Mineral - CETEM - Ministério da Ciência e Tecnologia \\ E-mail: zcastilhos@cetem.gov.br \\ ${ }^{4}$ Scitech Environmental Science And Technology Ltda.
}

\begin{abstract}
There are emissions of mercury to the atmosphere, soil and rivers of the Brazilian Amazon stem from many sources. Once in the atmosphere, the metal is oxidized and immediately deposited. In the water, the transformation to methylmercury takes place mostly by the action of microorganisms. The formation of methylmercury increases the dispersion and bioavailability of the element in the aquatic environment. Methylmercury can be assimilated by plankton and enters the food chain. The concentration of mercury increases further up in the trophic levels of the chain and reaches the highest values in carnivorous fishes like tucunare. Therefore, mercury emissions cause the contamination of natural resources and increase risks to the health of regular fish consumers. The objective of this work was to study the bioaccumulation of mercury in tucunares (Cichla sp.), top predators of the food chain. The fishes were collected at two locations representative of the Amazonian fluvial ecosystem, in the state of Pará, Brazil, in 1992 and 2001. One location is near a former informal gold mining area. The other is far from the mining area and is considered pristine. Average values of total mercury concentration and accumulation rates for four different collection groups were compared and discussed. Tucunares collected in 2001 presented higher mercury contents and accumulated mercury faster than tucunares collected in 1992 notwithstanding the decline of mining activities in this period. The aggravation of the mercury contamination with time not only in an area where informal gold mining was practiced but also far from this area is confirmed.
\end{abstract}

Keywords: mercury; bioaccumulation; tucunares, Amazon.

\section{Bioacumulação de Mercúrio em Tucunarés da Amazônia Brasileira (Cichla sp., Cichlidae, Perciformes)}

\section{RESUMO}

As emissões de mercúrio para a atmosfera, solo e rios da Amazônia Brasileira provêm de diversas fontes. Uma vez na atmosfera, o metal é oxidado e se deposita imediatamente. $\mathrm{Na}$ água, a transformação para o metilmercúrio ocorre principalmente pela ação de 
microrganismos. A formação do metilmercúrio aumenta a dispersão e biodisponibilidade do elemento no ambiente aquático. O metilmercúrio pode ser assimilado pelo plâncton e entra na cadeia alimentar. A concentração do metal aumenta à medida que se ascende nos níveis tróficos da cadeia e atinge os valores mais elevados em peixes carnívoros como o tucunaré. Dessa forma, as emissões de mercúrio causam a contaminação dos recursos naturais e aumentam os riscos para a saúde dos consumidores habituais de pescado. O objetivo deste trabalho foi estudar a bioacumulação de mercúrio em tucunarés (Cichla sp), predadores de topo da cadeia alimentar. Os peixes foram coletados em dois locais representativos do ecosistema fluvial Amazônico, no estado do Pará, em 1992 e 2001. Um local é próximo de uma antiga área de garimpo de ouro. O outro é distante da área de mineração sendo considerado prístino. Os valores médios da concentração total de mercúrio e as taxas de acumulação para quatro grupos de coletas diferentes foram analisados. Apesar do declínio das atividades de mineração artesanal, os tucunarés coletados no ano 2001, apresentaram maiores teores de mercúrio e acumularam mercúrio mais rapidamente, que os tucunarés coletados no ano 1992. Confirma-se o agravamento da contaminação por mercúrio com o decorrer do tempo não apenas em uma área onde antes existiu garimpo de ouro, mas também longe desta.

Palavras-chave: mercúrio; bioacumulação; tucunarés; Amazônia.

\section{INTRODUCTION}

Anthropogenic emissions have caused an increment of mercury concentration in the environment and of its exposition to living organisms. Fish consumption represents the major exposition route of mercury to humans. Methylmercury is a stable chemical and the most toxic and bioavailable form of mercury (WHO, 1990). Methylmercury is considered a powerful neurotoxin and its capacity to pervade biological membranes, as placenta, puts the health and normal development of human fetus brains in serious risk according to epidemiologic studies (Grandjean et al., 1997). Methylmercury is responsible for a few mass contaminations. The most famous took place in the Japanese city of Minamata in the late 1950s. In this episode, the highly toxic potential of methylmercury was detected for the first time (Lacerda and Salomons, 1998).

In the late 1970s, several factors such as the increase in gold prices, deterioration of the economic and social situation and the scarcity of jobs in Brazil, stimulated informal gold mining (garimpo) in the Amazon and Center-West regions of the country. A contingent of more than 500,000 informal miners or gold washers (garimpeiros) was mobilized in these regions at the beginning of the 1980s. The garimpeiros obtain gold from alluvium deposits and secondary gold by amalgamation with mercury. The Brazilian gold production in 1989 reached the maximum value of 113 tons from which $89 \%$ were produced in the garimpos (Vale, 2002). The current situation is different and gold production is mostly industrial and in a smaller scale. However, the historical amount of mercury emitted in the Amazon is high, being responsible for increasing the mercury content in indigenous freshwater fishes with the ensuing health risks to the communities that feed on them. High mercury contents in fishes and men have been observed even far from the mining areas. Mercury emissions to the environment resulting from garimpo activities were the major source of mercury release in the 1980s and 1990s (Lacerda and Salomons, 1998). The existence of a large amount of macrophytes plants in the water bodies, the deforestation for agriculture, the creation of water reservoirs for hydroelectric plants, the slightly acid nature of the waters and the overflow of rivers in the rainy season contribute to the high methylation rates with the corresponding 
increase on the mercury availability for aquatic biota in tropical environments (Lacerda and Salomons, 1998).

An effective way of evaluating the contamination level of an environment is by examining the contamination of its top predators. Amazonian tucunares (Cichla sp.) are important neotropical carnivorous fishes. In this work total mercury concentration in the muscle and mercury accumulation rates in tucunares collected in 1992 and 2001 at two regions representative of the Amazonian fluvial ecosystem were compared and discussed.

\section{MATERIALS AND METHODS}

The first sampling location is close to an area where gold miming activities had previously occurred. It is a section of the Tapajos River between the towns of Itaituba and Jacareacanga $\left(04^{\circ} 15^{\prime} 23^{\prime \prime} \mathrm{S}-55^{\circ} 54^{\prime} 33^{\prime \prime} \mathrm{W}\right)$. The second site is situated in the Maica lakes complex near the city of Santarem in the margin of Amazon River $\left(02^{\circ} 25^{\prime} 11^{\prime \prime} \mathrm{S}-54^{\circ} 42^{\prime} 16^{\prime \prime}\right.$ $\mathrm{W})$ and $250 \mathrm{~km}$ downstream of the first location. These areas are shown in Figure 1.

In the first location, 28 specimens of tucunares Cichla sp. and 52 specimens of tucunares Cichla monoculus were captured in 1992 and 2001 respectively. In the second location 33 individuals of the Cichla sp. species and 26 individuals of the Cichla monoculus were collected in 1992 and 2001 respectively.

Total length $(\mathrm{cm})$, total weight $(\mathrm{g})$ and total mercury concentration $(\mu \mathrm{g} / \mathrm{g})$ in the muscles of the fish were measured for each tucunare captured (Castilhos et al., 1998; Souto, 2004). Values are presented as mean \pm standard deviation (SD).

The total mercury concentration was measured by an atomic absorption spectrophotometer (A-GNARIAN model) that uses a vapor generation device - VGA (CVAAS) - to generate the cold mercury vapor. The samples were digested in sulfuric and nitric acids solution in the presence of vanadium pentoxide $0.1 \%$. The oxidation was completed by adding potassium permanganate $6 \%$ until the fixation of the violet color. Immediately before the determination of mercury, the excess of permanganate was reduced with hydroxylamine 50\% (Campos and Curtis, 1990). IAEA reference standards of muscular tissue of the fishes with a certified mercury concentration of $0.74 \pm 0.13 \mu \mathrm{g} . \mathrm{g}^{-1}$ were also analyzed providing a value of $0.73 \pm 0.08 \mu \mathrm{g} . \mathrm{g}^{-1}$.

Statistical analyses were performed using STATISTICA_6.0 for Windows (StatSoft, Inc 1984e2001, USA). After verification of the non-normal distribution of each data set, an analysis of variance was done by KruskaleWallis ANOVA. When required an additional Post hoc test (ManneWhitney U-test) for the identification of the differences between the groups.

A linear regression was performed to determine the relationship between total length and the concentrations of mercury in muscle tissue. 


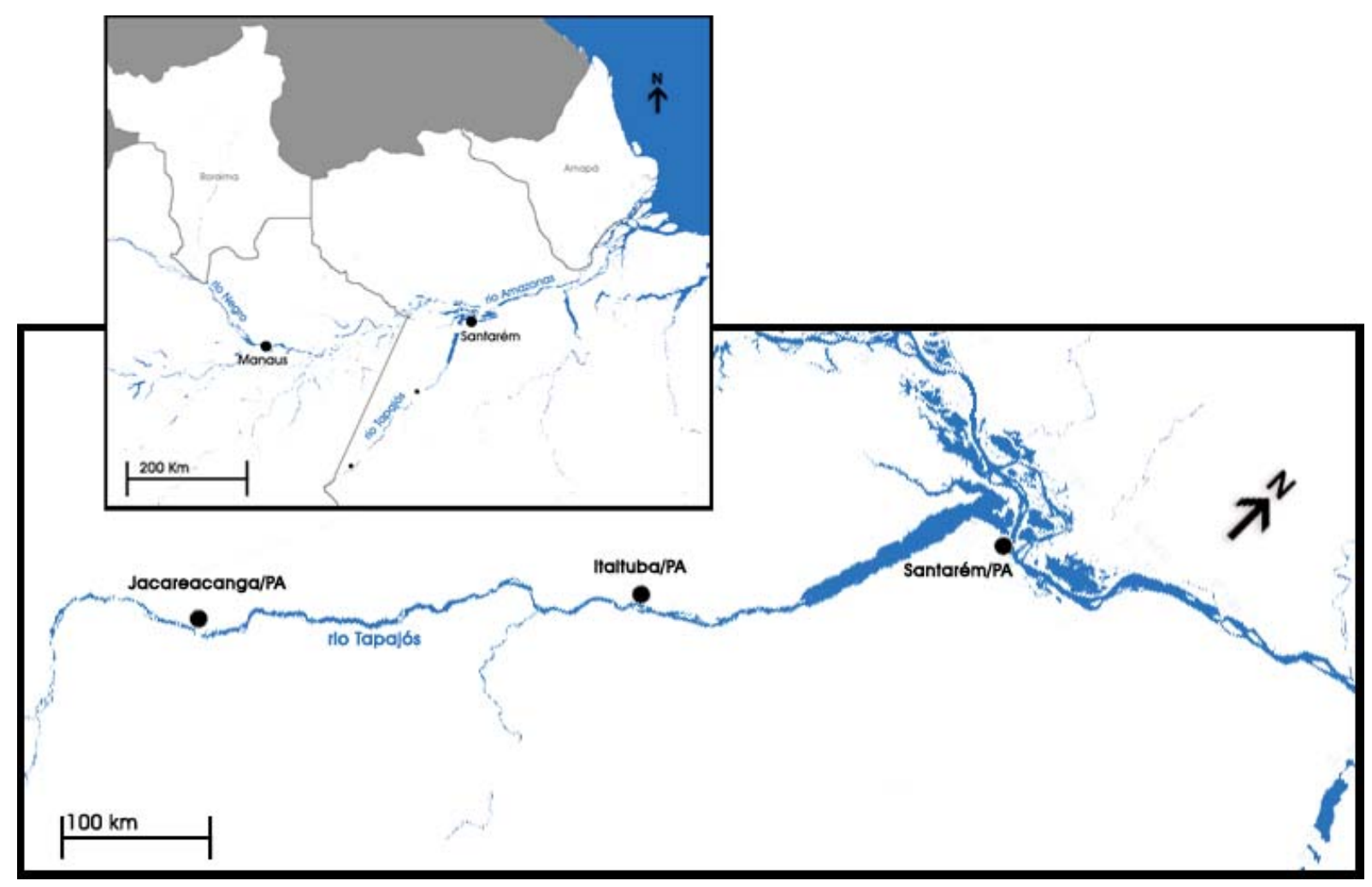

Figure 1. Map of the sample collecting areas. 1) Maica Lake situated in Santarem city (Not directly mercury impact). 2) Itaituba city (Mining impacted area). 3) Jacareacanga city (Mining impacted area). Picture adapted from Roulet et al. (2000).

\section{RESULTS AND DISCUSSION}

The average values and standard deviations of total length, total weight and total mercury concentration in the muscle for each collection group in 1992 and 2001 are given in Table 1.

The analysis of variance (KruskaleWallis ANOVA) analysis showed no significant differences $(\mathrm{N}=139 ; \mathrm{H}=1.74 ; \mathrm{p}>0.05)$ for the lengths and body weight $(\mathrm{N}=111 ; \mathrm{H}=3.47$; $\mathrm{p}>0.05)$ among the different groups. However the analysis of variance showed a significant difference $(\mathrm{N}=139 ; \mathrm{H}=96.65 ; \mathrm{p}<0.01)$ for the total mercury concentration among the different groups.

A Post hoc test (ManneWhitney U-test, 95\% confidence interval) analysis showed significant difference for total mercury concentrations of each group. The total mercury concentrations were plotted as a function of the total length of the fishes for each collection group/year and the data were linearly fitted according to Figure 2. Since the total length of the fishes can be associated with their ages (time), there is an increase of concentration with time for all collection groups. This result suggests that fishes of the two sampling sites accumulated mercury throughout their lives. A greater slope indicates a higher accumulation rate. For the same location, fishes collected in 2001 accumulated mercury faster than the specimens captured in 1992. The higher accumulation rate corresponds to fishes of the Tapajos River/2001 followed by fishes of the Maica lakes/2001. Moreover, fishes captured close to garimpos accumulated mercury faster than fishes collected far from the mining sites in the same year. 
Table 1. Average values of total length, body weight and total mercury concentration in the muscle $\left([\mathrm{Hg}]_{\mathrm{T}}\right) \pm$ Standard deviation in Cichla sp. for each location/year of collection.

\begin{tabular}{lcccc}
\hline \multicolumn{1}{c}{ Location/Year } & $\mathbf{N}$ & $\begin{array}{c}\text { Total } \\
\text { length } \\
\mathbf{( c m )}\end{array}$ & $\begin{array}{c}\text { Body weight } \\
\mathbf{( g )}\end{array}$ & $\begin{array}{c}{[\mathbf{H g}]_{\mathbf{T}}} \\
\mathbf{( \mu g / g )}\end{array}$ \\
\hline Maica lakes/1992 & 28 & $37.3 \pm 11.9$ & - & $0.12 \pm 0.05$ \\
Tapajos & 33 & $34.3 \pm 6.1$ & $655 \pm 428$ & $0.42 \pm 0.19$ \\
$\begin{array}{l}\text { River/1992 } \\
\text { Maica lakes/2001 }\end{array}$ & 52 & $34.8 \pm 4.3$ & $639 \pm 267$ & $0.24 \pm 0.11$ \\
$\begin{array}{l}\text { Tapajos } \\
\text { River/2001 }\end{array}$ & 26 & $34.0 \pm 4.2$ & $514 \pm 171$ & $0.73 \pm 0.23$ \\
\hline
\end{tabular}

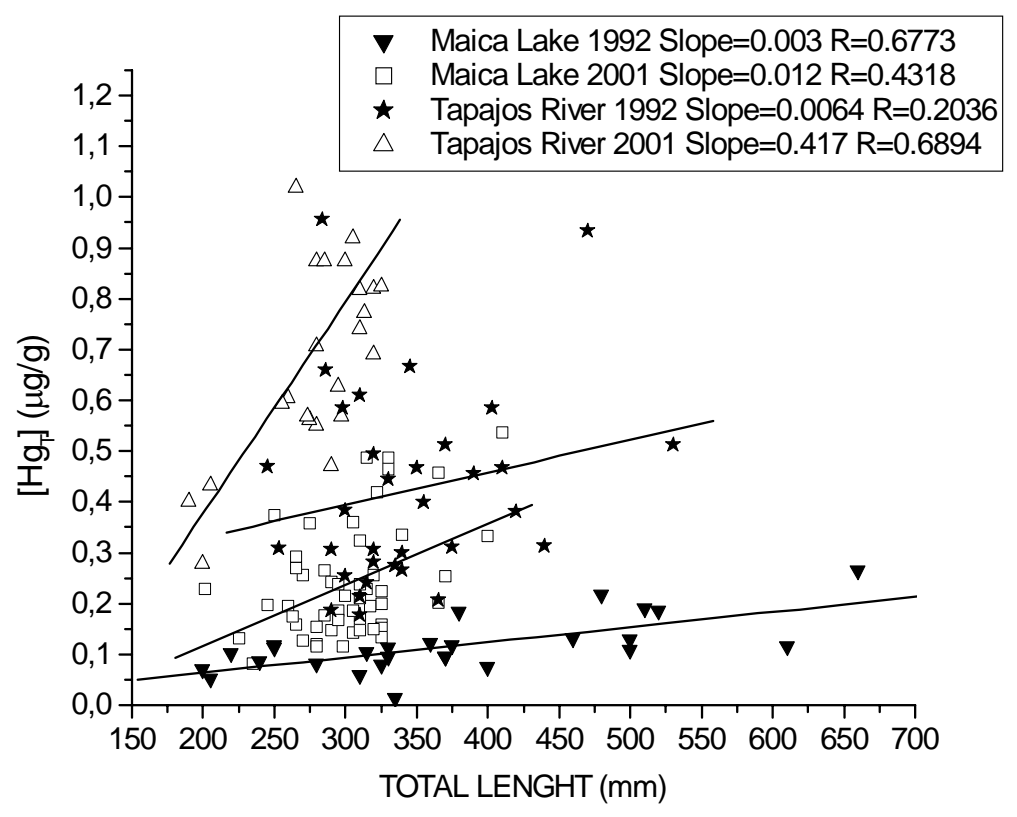

Figure 2. Values of total mercury concentration and total length of any fish for each collection group. Linear regression for each set of data.

Mercury is emitted to the environment mostly as a metallic vapor which can be oxidized in the atmosphere and immediately transported mainly by rain to freshwater bodies and oceans where is easily transformed into methylmercury mostly by microbial activity (Meech et al., 1997).

The methylmercury liberated to the water can be immediately incorporated by plankton which is consumed by species of the next trophic level of the food chain. Methylmercury is easily absorbed by these species but its elimination occurs rather slowly resulting in an increase of mercury content inside the organism with time (bioaccumulation). The amount of methylmercury increases when passing from an inferior to a superior trophic level (biomagnification), being low in aquatic plants, intermediate in invertebrates and high in fishes, carnivorous aquatic mammals and birds. Methylmercury is the only mercury species that experiences biomagnification and is practically the only mercury species present in 
carnivorous fish. The concentration of methylmercury in the tissues of carnivorous fishes can be a million times greater than in water (CCME, 2000).

The concentration of methylmercury in a top predator of the food chain, as tucunare, depends directly on its production in the aquatic environment. Thus, the bioavailability of methylmercury depends on the methylation capacity of the aquatic environment (Gill and Bruland, 1990). The activity level of the microorganisms and the amount of available $\mathrm{Hg}^{2+}$ are the main factors affecting the methylation rate. The activity of the microorganisms and the amount of $\mathrm{Hg}^{2+}$ are influenced by several factors such as the amount of organic carbon dissolved in water, $\mathrm{pH}$, local type of bacterial community and substratum where the methylation is carried out (Ullrich et al., 2001).

The fact that the amount of mercury found in tucunares was higher next to mining areas may suggest that gold mining increased the $\mathrm{Hg}^{2+}$ concentration in water causing higher loads of mercury in the fishes. The reason for this is that it is unlike that the natural conditions for the methylation of $\mathrm{Hg}^{2+}$ are more favorable near than far from the mining sites since the waters of Tapajos River and of Maica lakes have similar physical-chemical characteristics and are classified as clear waters (Sioli, 1984). It is important to detach, however the two bodies of water to be classified as to clear waters, these rivers drain different geologic areas, in way that its natural mercury concentration can be different. Moreover, the Maicá lakes receive influence from waters of Amazon during the flood, while the point above of Itaituba and Jacareacanga only of the Tapajós, what it can modify this clear water pattern.

Gold mining activities were responsible for the release of about 70 to 130 tons per year. Of these, more than 50\% were used in garimpos located in the Tapajos River basin (Lacerda and Salomons, 1998). The mercury is used to extract the gold contained in superficial alluvium deposits and its emissions to the atmosphere occur by active evaporation and passive degasification.

According to estimates of Meech et al. (1997) about $80 \%$ of the mercury used in gold extraction is emitted by active evaporation during the roasting of the amalgam and gold purification. Active evaporation occurs basically in the mining site since the garimpeiros generally do not use retorts or any other closed system to burn the amalgam. On the other hand, mercury emissions arising from bullion purification come about in the gold and silver trading shops located in populated places. During burning and re-burning of the amalgam the primary mercury species emitted to the atmosphere is the metallic vapor. As a result of its high vapor pressure, the elementary mercury in air is predominantly in the gaseous phase instead of associated to particulates as other transition metals.

The mercury oxidation process in the atmosphere is accelerated in the clouds in the presence of ozone and chlorine. Lindqvist and Rhode (1984) pointed out that mercury may remain in the atmosphere for 6 to 24 months in a dry climate. However, the burning of biomass during the dry season, which coincides with the mining season, augments the ozone concentration in the low atmosphere resulting in a very rapid formation of $\mathrm{Hg}^{2+}$.

Another important factor controlling the residence time of mercury in the atmosphere is the concentration of suspended particles in air and aerosol. During forest fires the concentration of particulates suspended in the air increases from $10-20 \mu \mathrm{g} . \mathrm{m}^{-3}$ to $700 \mu \mathrm{g} . \mathrm{m}^{-3}$ (Artaxo et al., 1998). Solid particles of dust and char from biomass burning are efficient traps for the mercury vapor present in the atmosphere and also can serve as oxidation sites to form $\mathrm{Hg}^{2+}$ (Artaxo et al., 1998).

The increase of ozone concentration and particulate load in the atmosphere causes a short residence time of mercury in this compartment due to the fast oxidation of the mercury vapor which can be easily removed by the frequent rainfalls occurring in the tropical environment. 
A large scale characterization of the atmospheric mercury concentration in the Amazon basin was conducted by Artaxo et al. (2000). High mercury concentrations in the atmosphere were observed in areas where gold mining activities existed at the time of sampling. Coincidently in these areas high amounts of aerosol particles arising from the intensive annual burning of biomass during the dry season (period where the measurements were made) also existed. Very low mercury concentrations were found in virgin or pristine areas of the Amazonian forest. These findings suggest that gold mining causes an increase of the mercury content in the atmosphere and correspondingly of its deposition rate. The result is an increase of $\mathrm{Hg}^{2+}$ concentration in the water bodies next to the mining areas.

Passive degasification takes place in any contaminated soil or water body and, in lesser scale, during mining, due to the high temperatures at the mining places and high volatility of metallic mercury. The contaminated rejects are a significant source of mercury emission to the atmosphere by passive degasification.

The metallic mercury present in water is insoluble and practically non-reactive under the regular aerobic conditions existing, at least for decades, on the majority of aquatic environments. Thus, metallic mercury is barely available to be captured by living organisms and is preferentially incorporated to the sediment. Metallic mercury does associate neither with organic matter nor with the mineral clay that constitute the sediments being partially transformed into methylmercury. The fate of metallic mercury introduced in the aquatic environment depends on the physical-chemical characteristics of the water.

The mercury must be oxidized to be more soluble in water. Species or complexes of $\mathrm{Hg}^{2+}$ are formed. These species or complexes are more reactive than metallic mercury. The reactions of methylmercury formation are faster when $\mathrm{Hg}^{2+}$ compounds exist (Ullrich et al., 2001).

The mercury concentration in tucunares increased in the two locations from 1992 to 2001 notwithstanding the decline of mining activities in this period. After the drop in the mining activities the main sources of mercury emissions in the Amazon are the release from biomass and soil during forest burning and the release from gold mining rejects accumulated in the water and soil throughout the years. Furthermore, the iron-rich soils typical of this region contain appreciable amounts of mercury and the erosion of these soils, after deforestation and farming, enhances the leaching of the metal accumulated to the water bodies (Roulet and Lucotte, 1995).

According to Meech et al. (1997), approximately 90 tons of mercury per year is emitted to the atmosphere as a consequence of biomass burning. The use of fire is deeply enrooted in the Amazonian culture. Forest burning converts the forests into farming lands or pastures and controls the proliferation of invasive plants. It is the cheapest method of soil fertilization for new agricultural areas (Nepstad et al., 1999). Intentional burnings are usually performed at the end of the dry season when the crops are easier to burn and the forests are more vulnerable. The situation is aggravated when the burnings run off control. It is particularly difficult to keep the fire under control in the regions where seasonal droughts occur (Nepstad et al., 1999).

Accidental fires frequently occur within the occupation borders of the Amazon and cause extensive ecological and economic damages. Several factors contribute to the occurrence of these fires. The problem of accidental fires has worsened in the last years of the period due to the higher frequency and intensity of the El Niño phenomenon which is associated with severe droughts throughout the region. The rain decline dried the soil along great forest areas and created an enormous potential for forest fire occurrence during the 1998 dry season (Nepstad et al., 1999). Accidental fires in the Amazon can intensify in the next years. A team 
of climatologists have recently concluded that the higher frequency of this event is connected with the accumulation of carbon dioxide in the atmosphere and therefore could represent the beginning of a long-range climatic change. The fall in the precipitation levels in the region is one of the foreseen effects of the large scale deforestation in the Amazonia.

The fire problem is particularly difficult to solve since it results from a complex interaction of biophysical and socioeconomic factors occurring within the occupation borders. It is hard for the government to regulate the burnings since they rapidly take place in remote places causing difficulties to identify how they started, what damages were involved and who are responsible for eventual harms to properties and ecosystems (Nepstad et al., 1999).

\section{CONCLUSIONS}

The utilization of the tucunare species, of great ecological value and an important resource for riverine populations, can be considered a quite appropriate tool to show one facet of the irresponsible occupation of the Brazilian Amazon in the last decades.

\section{ACKNOWLEDGEMENTS}

The authors are grateful to the Brazilian government for supporting this research and to Dr. Zuleica Carmem Castilhos - CETEM and Dr. Paulo Sergio Souto - UFRA for supplying the mercury concentrations in tucunares. Ysrael Marrero Vera thanks CAPES for granting a M.Sc. scholarship.

\section{REFERENCES}

ARTAXO, P.; CAMPOS, R. C. de; FERNANDES, E. T.; MARTINS, J. V.; XIAO, Z.; LINDQVIST, O. et al. Large scale mercury and trace element measurements in the Amazon basin. Atmospheric Environment, Amsterdam, v. 34, p. 4085-4096, 2000.

ARTAXO, P.; FERNANDES. E. T.; MARTINS, J. V.; YAMASOE, M. A.; HOBBS, P. V.; MAENHAUT, W. et al. Large scale aerosol source apportionment in Amazonia. Journal of Geophysical Research, Washington, v. 103, p. 31837-31848, 1998.

CAMPOS, R. C. de; CURTIS, A. J. Riscos e conseqüencias do uso de mercúrio. In: SEMINÁRIO NACIONAL FINEP, 1., 1989, Brasília. Trabalhos apresentados... Rio de Janeiro: FINEP: 1990. p. 110-134.

CASTILHOS, Z. C.; BIDONE, E. D.; LACERDA, L. D. Increase of the background human exposure to mercury through fish consumption due to gold mining at the Tapajós river region, Amazon. Bulletin of Environmental Contamination and Toxicology, New York, v. 61, p. 202-209, 1998.

CANADIAN COUNCIL OF MINISTERS OF THE ENVIRONMENT (CCME). Methylmercury: Canadian tissues residues guideline for the protection of wildlife consumers of aquatic biota. Ottawa: Environment Canada, 2000.

GILL, G. A.; BRULAND, K. W. Mercury speciation in surface fresh water systems in California and others areas. Environmental Science and Technology, Washington, v. 24, p. 1392-1400, 1990. 
GRANDJEAN, P.; WEIHE, P.; WHITE, R. F.; DEBES, F.; ARAKI, S.; YOKOYAMA, K. et al.. Cognitive deficit in 7-year-old children with prenatal exposure to methylmercury. Neurotoxicology and Teratology, Amsterdam, v. 19, p. 417- 428, 1997.

LACERDA, L. D.; SALOMONS, W. Mercury from Gold and Silver Mining: a chemical time bomb? Berlim: Springer-Verlag, 1998.

LINDQVIST, O.; RHODE, H. Atmospheric mercury a- review. Tellus B, Stockholm, v. 37, p. 136-159, 1984.

MEECH, J. A.; VEIGA, M. M.; TROMANS, D. Mercury emissions and stability in the Amazon region. Canadian Metallurgical Quarterly, Kingston, v. 36, p. 231-239, 1997.

NEPSTAD, D. C.; MOREIRA, A.; ALENCAR, A. A. A floresta em chamas: origens, impactos e prevenção de fogo na Amazônia. Programa Piloto para a Proteção das Florestas Tropicais do Brasil. Brasília: IPAM, 1999.

ROULET, M.; LUCOTTE, M. Geochemistry of mercury in pristine and flooded ferralitic soils of a tropical rain forest in French Guiana, South America. Water, Air, and Soil Pollution, Amsterdam, v. 80, p. 1079-1088, 1995.

ROULET, M.; LUCOTTE, M.; RHEAUlT, I.; GUIMARÃES, J. R. D. Methylmercury in the water, seston and epiphyton of an Amazonian River and its floodplain, Tapajós River, Brazil. Science of Total Environment, Amsterdam, v. 261, p. 43-59, 2000.

SIOLI, H. The Amazon limnology and landscape ecology of a might tropical river and its basin. Dordrecht: W. Junk Publishers, 1984. Vol. 4, p. 15-46.

SOUTO, P. S. Risco ecológico associado a contaminação mercurial em ecossistemas aquáticos da Amazônia: região do rio Tapajós, Estado do Pará, Brasil - caracterização através de biomarcadores no gênero Cichla (tucunarés). 2004, 158f. Tese (Doutorado em Geoquímica Ambiental) - Instituto de Química, Universidade Federal Fluminense. Rio de Janeiro, 2004.

VALE, E. Economia mineral do ouro no Brasil In: Extração de Ouro: princípios, tecnologia e meio ambiente. Rio de Janeiro: Centro de Tecnologia Mineral (CETEM), 2002.

ULLRICH, S. M.; TANTON, T.W.; ABDRASHITOVA, S. A. Mercury in the aquatic environment: a review of factors affecting methylation. Critical Reviews in Environmental Science and Technology, Philadelphia, v. 31, p. 241-293, 2001.

WORLD HEALTH ORGANIZATION (WHO). Methylmercury in environmental health criteria 101. Geneva: WHO, 1990. 